\title{
3. Claim, culture and effect: property relations and the native title process
}

\section{Katie Glaskin}

\begin{abstract}
Because the subjective necessity and self-evidence of the commonsense world are validated by the objective consensus of that world, what is essential goes without saying because it comes without saying: the tradition is silent, not least about itself as tradition; customary law is content to enumerate specific applications of principles which remain implicit and unformulated, because unquestioned ...
\end{abstract}

(Bourdieu (1977: 167), original emphasis).

Since the advent of the Native Title Act 1993 (Cwlth) (NTA), Indigenous Australians have been able to make claims to their traditional lands. Patton (2000: 28) describes Aboriginal or native title as representing 'an attempt to translate indigenous peoples' spiritual and economic relation to their land into a form of property right recognisable by the common law'. One could argue that native title represents more a codification of some Aboriginal property rights than it does an attempted translation, given that native title is limited to only certain rights in lands and waters, and has not thus far included the recognition of incorporeal property rights (Glaskin 2003). Notwithstanding the limitations of native title and its capacity to recognise only certain Indigenous property rights, one consequence of the attempted 'translation' and subsequent codification of native title rights and interests through the native title process is a legal interrogation of certain aspects of Indigenous Australians' relations to land. To gain recognition of their native title, Indigenous claimants are required to demonstrate continuity with the 'traditional laws and customs' - those practiced by their antecedents at the time of the acquisition of sovereignty by the British Crown - from which their native title rights and interests are derived.

Property is inherently relational: it involves a person owning something as against other people, that is, in relation to them; or exercising rights and obligations with respect to the thing owned, as against others (Hallowell 1955: 238-9). A condition of demonstrating native title is that Indigenous claimants must articulate and objectify aspects of their property relations in response to the legislative requirements of the NTA. This objectification of relations to country occurs not only at a level that is in some sense external to Indigenous groups, in terms of a determination of native title (where a determination is ultimately made: not all claims result in determinations), but also occurs amongst and by Indigenous people themselves in response to various processes associated 
with making claims. These objectifications, I argue, have the potential to affect social relations within Indigenous groups, and hence their property relations.

This chapter examines some of the effects of participating in native title processes amongst Bardi and Jawi people, who live in the northwest Kimberley region of Western Australia. My focus here is on the native title processes they engaged in prior to the determination of their native title. Work on their combined native title claim first began in 1994, when the Native Title Act was quite new. The case was heard at various times between the years 2001 and 2004. In 2005, French $\mathrm{J}$, the second trial judge to hear the case, made a determination, ${ }^{l}$ and in February 2007 this determination was appealed before the Full Federal Court. At the time of writing the outcome from this appeal was pending. For Bardi and Jawi, the prolonged (and often onerous) process of claiming country has had a number of impacts, effects and consequences, apart from those arising from this determination and the appeal process. As they engaged with native title, some of the 'compelling but largely implicit premises of [their] cultural practice' (Scott 1993: 322) have been brought into the realm of discourse, objectifying aspects of their 'traditional laws and customs' and relations to country. Based on fieldwork carried out between 1994 and 2003, I argue that these objectifications, in turn, have had implications for the articulation and enactment of property relations amongst Bardi and Jawi peoples. By objectification, I follow Strathern (1999: 13) to mean 'the way in which entities are made into objects through the relations which people have with one another'.

Thomason (1982: 124,126) describes objectification as 'necessarily' involving a "distancing" of man from his products', where these products become 'objects' or 'things', and 'are taken to be, in some sense, "external", "factual", "independent of how we might think about them ..."'. In the native title context, aspects of Indigenous culture such as 'laws and customs' and 'rights and interests' are made visible and conceptually divisible (sometimes extinguishable) by the political, economic and legislative circumstances in which such claims are and can be made. The articulation of native title rights and interests is an example of the way in which objectification can go, deriving from a set of relations to land a set of rights that may be apprehended as 'things', in some sense external from those relations from which they are sourced (Glaskin 2003).

In Wagner's (1981 [1975]: 34) view, 'when culture is assumed self-consciously', identity must always be involved, although 'identity by no means exhausts or explains the usage'. Roosens (1989: 150) argues that 'in order to see and use one's own culture as a right, one must first have gained distance from that culture'. Where indigenous claims are tested within legal contexts, the kinds of cultural characteristics indigenous groups are likely to ascribe to themselves and consider

1 Sampiv State of Western Australia [2005] FCA 777. 
relevant highlight those aspects of their cultures that are elicited (and indeed required to prove their claims) within those contexts. As writers such as Barth (1970: 38) and Roosens (1989: 12) suggest, only some features of a particular culture become diacritic markers of social or cultural boundaries, and this phenomenon of cultural differentiation reflects on intercultural communication and social action across these 'boundaries'. Objectification of certain cultural features over others becomes especially evident where indigenous peoples assert rights and the state seeks to recognise these, as in claims to native title. As I argue, the effects of these responses within indigenous groups is to foster self-conscious definitions of their culture at the least, and may also have an important role in internal group definition and reproduction, especially where such objectification becomes reified or codified in some form.

\section{Law and culture}

Like many Australian Indigenous peoples, Bardi and Jawi have long objectified certain facets of their culture, like the ancestral figures whose deeds and authority are inscribed in landscape and in ritual. The English word they typically use to encompass the kinds of notions that are embedded in the English word 'Dreaming' is 'the Law'. ${ }^{2}$ 'The Law' is distinct from 'Law business'; the latter specifically refers to ritual activity which certain ancestral beings 'gave' them to follow, while implicit in the former is the totality of the ancestral beings' activities and precepts; it encodes the entirety of their religious belief and mythopoeia.

Most Bardi and Jawi view 'Law business' (male ritual) as the foundation of other aspects of 'culture'. The status accorded to male ritual in their society makes it one of the most significant and potent of the objectifications of the ancestral creative deeds. Most Bardi and Jawi who live in their country are involved in the practice of Law, which is a religious obligation of utmost importance to them. Many others who are resident in Broome or Derby travel up the peninsula to take part in ritual with those who are resident at communities in the peninsula. Young boys are 'put through' the Law every year. Women participate in many aspects of Law too, such as Anggwuy, the public ceremony before the boys are secluded for initiation, in Nguril, the public ceremony to welcome the boys out from the bush following Irrganj; and in a restricted way, in Ululung (Bagshaw 1999: 29). Men participate in all facets of Law business, and much of the Law is restricted and secret male-only business.

Bardi and Jawi consider their Law to be integral to their being-in-the-world, and consider it inalienable in the sense that, as one senior Jawi man described it, 'we can't stand, we belong to Law'. ${ }^{3}$ Myers' observations regarding 'the

2 Bardi do not have a single, collectively espoused term to encompass the concept of 'Dreaming' or 'Dreamtime'; see Glaskin (2005) for further discussion of this.

3 Khaki Stumpagee Video Transcript 2001, p. 32. Interview with Geoffrey Bagshaw at Nillargoon outstation, Iwanyi, Sunday Island 16th July 1997, transcribed by Katie Glaskin. Tendered in the Federal 
Dreaming' (which he equates with 'the Law') among the Pintupi are equally applicable to Bardi Law:

The Dreaming - 'the Law' - provides a moral authority lying outside the individual and outside human creation. It is not his idea or his will. Thus, although the Dreaming as an ordering of the cosmos is presumably a product of historical events, such an origin is denied. These human creations are objectified - thrust out - into principles or precedents for the immediate world (1986: 69).

As Myers suggests, Indigenous Australians have long possessed their own techniques of objectification, whereby their 'culture' has been revealed to them. Like other Australian Indigenous groups such as the Pintupi and Walbiri, Bardi and Jawi participate in these 'objectifications already created by the ancestors, and are [consider themselves] bound to them' (Munn 1970: 157). Thus their Law - the equivalent of Munn's (1970: 157-8) 'mode of orientation' - 'mystifies human agency in the construction of forms of sociality' assimilating events 'to a pre-existing order which is objectified in features of the local landscape' (Rumsey 1994: 121; and see Merlan 1998: 215-16; Myers 1986: 286-8).

For Bardi and Jawi, like numerous other Kimberley peoples, the phrase 'Law and culture' is a shorthand way to emphasise the distinctiveness of their indigenous life-world. ${ }^{4}$ Strathern's (1999: 128) comments on 'culture' are appropriate to Kimberley Aboriginal usage of the term: 'in borrowing the concept of "culture", people appear to be doing what is done everywhere, fastening on to certain "customs" as diagnostic of their way of life ... culture/kastom is also used to signify difference'. The 'Law and culture' linkage and word order emphasises that Law, in a primordial sense, comes before 'culture'; Aborigines who have 'no Law' (who have ceased to practice Law) are often characterised by Bardi (at least) as having 'no culture'. Conversely, Aborigines who practice Law are 'culture people'. For Bardi and Jawi, humans are not the only beings with 'Law and culture'; dugongs especially, but turtles and other marine species are conceptualised as possessing ('they got') 'culture', because they have 'their own Law' (and see Rouja 1998: 244). This characterisation of these species as having their 'own Law' is based on their observable traits, their interactions with other members of their species and their behaviour (seasonality, mobility and foraging habits) within their marine environment. The predictability and immutability of their conduct gives rise to these creatures as being considered Law-like, and hence possessing 'culture'.

Court of Australia, Western Australia District Registry General Division, Paul Sampi $v$ State of Western Australia, WAG 49/1998.

4 For example, KALACC, the Kimberley Aboriginal Law and Culture Centre located in Fitzroy Crossing, specifically promotes indigenous 'Law and culture'. 
Bardi and Jawi are proud of their culture, and many people assiduously collect objects reflective of it. Traditionally, they traded objects such as boomerangs (irrgil), hairbelts (arnala), engraved pearlshells (riji), hairbelts attached to plain pearl shells (baali-guwarn) and mangrove log rafts (galwa in Bardi; biel-biel in Jawi). Natural resources like red ochre (bidimarr) and white ochre (maanga) were also traded. Such trade or exchange occurred amongst Bardi and Jawi, and with other neighbouring and more distant Aborigines. Some of these traditional objects of exchange appear in contemporary Bardi personal collections today.

Along with various artifacts, most Bardi houses contain prominent photographic displays of their kin painted up and dressed for ceremony, as well as photographs of the 'old people' from previous generations. Many people also collect taped recordings (both amateur and professional) of traditional songs, and published and unpublished material on Bardi and Jawi culture and history. Several people have told me of their desire to set up a cultural centre, either at One Arm Point, or smaller displays at their outstations, with a view to engaging in cultural tourism. This is one of the few avenues for developing Indigenous business enterprise in the area. Some Bardi people already engaged in small-scale tourism ventures see tourist interest as also providing some cultural recognition, given the evident expertise in their own culture that they can readily display in these contexts. Since the early 1990s, some Bardi have been making home videos of traditional methods of cutting up dugong and turtle, identification and use of bush foods, and public aspects of ritual, including preparations like the painting and adorning of initiates, hairbelt spinning, and boomerang and shield production. These videos have proved to be popular with other members of the Bardi and Jawi community, among whom they are widely disseminated. Many of the videos are used in classrooms at One Arm Point and Lombadina; both schools have Bardi language programs as well. ${ }^{5}$

Bardi collection and recording of cultural material reflects considerable pride in their culture. Such practices are also illustrative of a concern for cultural preservation and reproduction, as against an implicit-and frequently explicit - acknowledgment that the terms in which their culture is expressed is changing with increasing engagement with a modernising world. In this respect, native title is the latest in a series of legislative regimes which they have encountered, but is distinct from them, both because it is legislation aimed at recognising their traditional property entitlements, and correspondingly because of its emphasis on the 'traditional laws and customs' that give rise to these. Consequently, engagement with native title has quite different effects amongst Bardi and Jawi than those produced through previous historical and legislative encounters (which are more fully explored in Glaskin 2002). As I demonstrate briefly below, while certain aspects of their culture have been objects of interest

5 Although some Jawi words are still used, the language itself is no longer spoken. 
historically, these are distinct from those aspects of their culture (in particular, of their property relations) that are central to their engagement with the native title process.

\section{A historical view}

Sunday Island mission was established on the Jawi island of Iwanyi (Sunday Island) in 1899. Originally established as a non-denominational mission by the pearler Sydney Hadley, it was taken over by the United Aborigines Mission in 1923, and, with the exception of an unsuccessful relocation attempt to Wotjulum on the eastern side of the King Sound (1934-5), remained operational at the island until 1962. Following its closure, most of the Jawi and Bardi people who had lived at the island moved to Derby, where their children had been relocated in order to attend school. In 1972, without government assistance, they returned to the Dampier Peninsula where they established the community of One Arm Point on the Bardi mainland. Also on the mainland, the Pallottine order of the Catholic Church set up Lombadina mission in 1910, which is today a secular Aboriginal community. (Djarindjin Aboriginal community, established in the 1980s, is situated immediately adjacent to Lombadina). Prior to the establishment of the missions in Bardi and Jawi country, the discovery of rich pearling grounds had brought pearling fleets into the area from the early 1880s, and interactions with the pearlers constitutes the beginning of sustained contact with Europeans in this region.

From the earliest days of colonial contact, missionaries and other Europeans who lived in close proximity to Bardi and Jawi peoples made distinctions between some cultural practices (which were considered acceptable) as against others (which were not). During the early period of the United Aborigines Mission at Sunday Island, for example, the missionaries opposed overtly different cultural practices (various initiatory rites, tooth evulsion, cicatrisation, junior levirate marriage, traditional burial practices and so on) and sought to transform indigenous belief as well as practice (Glaskin 2002: 92-6).

Some aspects of Bardi culture also became objects of interest and attention during the early days of missionary operations in this region. Father Nicholas Emo, who began a short-lived mission at Disaster Bay and later worked at Lombadina mission, was 'a keen collector of native weapons and other tribal artefacts ... and the Dampierlanders, warming to his interest, had gladly bartered their handiwork for tobacco, sugar and tea' (Durack 1997: 220). Emo took notes on the 'customs' of both Nyul Nyul in the Beagle Bay area and Bard ${ }^{6}$ at Lombadina, and sought to identify marriage rules and kinship terms. ${ }^{7}$ Father Worms, a

6 Bard and Bardi are dialects of one language; Bard speakers are mainly associated with Lombadina and Djarindjin communities.

7 Copies of these workbooks are located in Records of Daisy M. Bates [MS 365] in the manuscript section of the National Library of Australia, Canberra. These workbooks were compiled by Daisy Bates on 
missionary at Lombadina between 1931 and 1955, wrote numerous articles on various aspects of Bard society and culture, showing that he had an active interest in these matters. ${ }^{8}$

The Western Australian government also had an interest in certain aspects of Aboriginal culture. In 1904, they produced a blank workbook ${ }^{9}$ and distributed it to those working with Indigenous people in Western Australia. Most of the workbook, entitled 'Native Vocabulary etc., compiled by [blank to be filled out]', calls for vocabulary, but at the back of the workbook there is some space (pp. 87-97) for 'questions'. Among the questions in the back of the workbooks were the following:

Question 5: Native modes of burial in the district?

Question 8: Game traps (kangaroo, emu, etc.), other methods of capture, description of?

Question 14: Legends, songs, and folklore (if any); legend of 'Bunnyar'?

Question 16: Extent of tribal country, and approximate number of natives in the district?

Question 17: Native names of tribes in the district?

Question 20: Do the tribes meet at any distant places for exchange or barter?

Question 23: Is cannibalism known to exist in the district?

Question 26: Any idea of a deity?

Question 27: Native beliefs in ghosts, or a future state?

Question 28: What beliefs have the natives in witchcraft, sorcery; and is there a 'boyl-ya' or sorcerer among the tribes in the district?

Both Sydney Hadley and W. H. Bird filled out these workbooks ${ }^{10}$ with respect to 'the natives' at Sunday Island mission. Bird's published accounts of Jawi language and 'customs' were based on the information in these books. ${ }^{11}$ The production and distribution of the workbook by the Western Australian government indicates that they were, in some fashion, interested in collating material that could be potentially useful in their governance of Aboriginal people.

behalf of the Western Australian Government, and 'despatched to all the postmasters, police officers, station owners and settlers in the State' (Bates 1985: 10).

8 See e.g. Worms $(1940,1942,1944,1949,1950,1957,1959)$; this is not an exhaustive list.

9 Copies of these workbooks are located in Records of Daisy M. Bates [MS 365] in the manuscript section of the National Library of Australia, Canberra. Bates evidently used these books during a certain period of her ethnographic investigations, although she is not the only one to have done so.

10 These are located in Records of Daisy M. Bates, MS 365, Box 27, Item Numbers 53/110, 53/111, and 53/116. Canberra: National Library of Australia.

11 See Bird (1910, 1911, 1915). 
Various objects and practices were also imbued with a commercial dimension following colonisation and engagement with the capitalist state. In the early days of the pearling industry, Bardi and Jawi traded artefacts (as they had done traditionally with other Aborigines) and resources (such as water and knowledge of where to find water) with pearling crews in exchange for introduced objects (like tobacco, flour, tea and alcohol). Sunday Island missionaries used Bardi and Jawi labour to harvest pearl shell, trepang, tortoise shell and trochus shell in order to sustain the mission economically. In this respect they were reliant not just on labour but on Bardi and Jawi knowledge of the marine environment, and on their navigational and sea-faring skills. Lombadina missionaries sought to capitalise on 'traditional' skills evident in artefact manufacture, teaching handicrafts at the mission for some years prior to World War II. When servicemen were stationed at Cape Leveque during the war, Lombadina residents traded wood-carvings and pearl shell ornaments with them (Robinson 1973: 173). In the 1960s, under the direction of the missionaries, Lombadina residents manufactured boomerangs for sale to boost the mission economy. ${ }^{12}$

The focused attention upon certain aspects of their society, in connection with various legislation, economic, technological and other changes arising from colonial encounters, are significant components of the conjunctural field in which Bardi and Jawi objectifications of some cultural elements have emerged post-colonisation. These objectifications have typically concentrated on outward, observable cultural forms, not on the 'inner workings' of a system of land and sea ownership. Indeed, in Australia as in other colonised countries, European powers justified their colonisation of indigenous peoples and the appropriation of their lands on a basis that was directly antithetical to such investigations: namely, that indigenous peoples were considered too 'primitive' to have had property laws or institutions of governance (Culhane 1998: 31). Hence Aboriginal property relations, while of research interest to some, have not been subjected to the kind of wholesale elucidation that engagement with native title processes has elicited, in which principles of inheritance, succession, rights and interests, boundaries, genealogies, and so on, are objectified for the purposes of interrogating whether native title can be recognised, and to what degree. ${ }^{13}$

Among Bardi and Jawi, it is the case that certain missionaries and anthropologists in the region have been interested in some less overt aspects of their 'culture'. The effects of these interventions, however, are distinct from those engendered by engagement with the native title process. In the latter, the communal emphasis

12 Father Kreiner, pers. comm., 15/12/94.

13 Of course, it may be the case that under the Aboriginal Land Rights (Northern Territory) Act 1976 (Cwlth), Aboriginal groups bringing claims under the legislation were required to similarly objectify their property relations. In Western Australia though, native title represents the first legislative opportunity for Indigenous Australians to have their traditional property rights recognised in legal form. 
of native title means that a broader socio-territorial group (not the individual) has been required to objectify their property relations in terms of 'traditional laws and customs': to articulate the 'rules' by which people are connected to country, by which they may succeed to it, and to elaborate on the kinds of rights and obligations that flow from their connection to country. While the elaboration of laws and customs that give rise to rights and interests in land is somewhat analogous to describing the external authority of 'the Law', these objectifications differ from those regarding 'the Law', both in kind - through stimulating explicit claims concerning individual or family group affiliations to publicly be made - and in terms of the conditions under which such objectifications occur-in response to the requirements of the NTA and in contexts where non-Indigenous people will test and adjudicate these claims regarding relations to country.

\section{Objectifying culture in the context of native title}

The outcomes of native title cases are finally determined through mediation or litigation. Both result in a legal determination of the extent to which native title rights and interests can be recognised at law, although in some cases, of course, determinations are made that native title cannot be recognised. The time between when work on a native title claim begins and its resolution can be quite substantial. In the Bardi and Jawi case, work on the claim formally began in 1994. Following litigation, a determination was made in 2005, and an appeal to the full Federal Court was heard in early 2007. During the years since work on the claim began, Bardi and Jawi have constantly been involved in various processes associated with their claim, including claim research, meetings to give legal instructions, to make communal decisions about land use in the area under claim in response to various developments, in mediations and negotiations, giving evidence in the Federal Court (in 2001 and again in 2003), attending other court evidence including the Federal Court appeal in this case in 2007, and more.

While some Aboriginal groups claiming native title may achieve consent determinations without facing litigation, all groups holding native title are required to form a prescribed body corporate (PBC) to hold and manage their native title rights and interests. My exploration of the effects of engaging with native title processes here focuses on discussions concerning the development of a PBC, which, amongst Bardi and Jawi, began long before the determination of their case in June 2005. The discussions I refer to here principally took place between 1996 and 1998. Further discussions have no doubt taken place since then, and it should be emphasised that my observations here are limited to those negotiations, and that these occurred pre-determination.

The Native Title Act requires an incorporated native-title holding body, a PBC, to hold the native title rights and interests that form the 'title' once the case has been determined. Like other corporations, a PBC requires a constitution outlining the rules and objectives by which the corporation will operate. Long before their 
native title claim had been heard in the Federal Court, the Kimberley Land Council-concerned about formalising land-use decisions in the area under claim - convened meetings with Bardi and Jawi claimants to discuss issues related to the development of a constitution for their PBC (this began in 1996; the claim was first heard in 2001). However, claimant discussions over these issues were not confined to larger public meetings, but spilled over into every-day talk among members of the claimant group. The issues were considered to be of much consequence, and most claimants saw themselves as vital stakeholders in the outcomes.

As members of the claimant group discussed the constitution for their $\mathrm{PBC}$, one aspect they felt had to be incorporated within the constitution concerned the role of the madjamadjin ('Law bosses' or senior ritual experts) within their society. The madjamadjin became defined in the draft constitution as 'those Common Law Holders who are recognised in accordance with Aboriginal Law, as having authority to speak about Aboriginal Law, in relation to Traditional Country'. Clause 11.3 of the draft constitution of the Bardi and Jawi PBC defined the role of the madjamadjin as including:

The Majamajin [sic] shall provide advice to the Governing Committee about membership application, assist in resolving disputes between members and advise the Corporation on all matters involving questions of Aboriginal Law.

During the course of their engagement with native title, as various internal disputes have arisen, Bardi have called upon the madjamadjin or 'bosses' to arbitrate matters having to do with their 'culture'. This has not provided straightforward solutions, for as one madja or 'boss' described it to me- this is my paraphrase - while the roles and responsibilities of the madjamadjin within the ritual context are circumscribed, outside of the ritual sphere, no such circumscription exists, and bosses do not necessarily hold uniform opinions or interpretations in relation to cultural matters (and see Keen 1997: 62). This was evident in a number of situations I witnessed and discussed with various people, and the reflection regarding the madjamadjin just described was derived from one of these conversations. ${ }^{14}$ Authority is often contested between madja, and resolution of non-ritual issues in which madja intervene is rarely the direct outcome of their actions alone.

Notwithstanding this, the bosses themselves as well as the majority of the claimant group held the view that where a contentious issue concerning land ownership arose, it was the bosses who needed to be called upon to arbitrate the issue. The codification of the role of the madjamadjin within the draft constitution represents the Bardi and Jawi attempt to translate and transpose

14 Kolig (1981: 83) describes a similar situation with respect to Fitzroy Crossing. 
traditional cultural principles into the context of a draft constitution for a PBC, reflecting what Sullivan (1997: 139) described in another context as being 'nothing less than an attempt at a self-governing structure reflecting customary Aboriginal Law.'

The incorporation of the role of the madjamadjin within the draft constitution, like other matters there that I will come to, stemmed from the public discussions concerning the reasons that Bardi and Jawi sought a determination of native title in the first instance. At the time of these discussions, most middle-aged and older Bardi saw native title as inseparable from aspects of their traditional laws and customs that underlay their claim to native title and provided its content. The formation of a PBC was, in their view, closely linked with the development of a particular kind of constitution - one they believed should adequately reflect the basis of their native title, that is to say, their 'culture'. Thus, the $1998 \mathrm{draft}$ constitution of their PBC sought to uphold Bardi and Jawi 'Law, language and culture'. While PBC constitutions do not require this kind of reflection of a group's law and custom, claimant perceptions that native title concerned their culture meant that they approached the development of the constitution from this basis. For example, one claimant expressed the view that 'seeing that this land claim is a countryman thing, it's about our culture, it's [the constitution] gotta be Aboriginal more than whiteman'. ${ }^{15}$ Another claimant expressed it this way:

Native title means getting our land back to use it traditionally, so we need to put [into the constitution] those traditional things first, they have to be implemented, but we have to put whiteman's side to protect us from pearlers, miners etc. But tradition needs to be foremost, our own culture. $^{16}$

In the context of these public discussions, one claimant ${ }^{17}$ pointed out that prescribed rules within a constitution could not ensure cultural reproduction. He said, 'can I strongly talk about this? I'm not against what's been said here, but culture should be taught from home. Sit down with jawul [ritual godparent/s] tell stories, who is related to who ...'. This man's observation indicated his reflexivity about the ways in which 'culture' is reproduced, stressing 'the home' as the place where this should occur; an apparently more organic and kin-based form of cultural reproduction than that represented by the codification of certain aspects of 'culture' within a PBC's constitution. His comment goes to the essence of one of the issues I wish to identify here: the effect of the native title process on cultural reproduction, which becomes potentially splintered between dynamism and codification, caught between 'tradition' and the objectification

15 Author's notes from claim meeting, 4 April 1997, emphasis added.

16 Author's notes from claim meeting, 4 April 1997, emphasis added.

17 Author's notes from claim meeting, 4 April 1997. 
of 'tradition', whether that occurs through PBC 'rules' or indeed through native title determinations. The coexistence of dynamism and objectification also means that, regardless of the extent to which 'rules' reflecting 'tradition' are written into a constitution, 'tradition' will remain open to negotiation and contestation, and therefore the $\mathrm{PBC}^{\prime}$ 's fidelity to 'tradition' will remain so too. And while dynamism and a codification of sorts (as exemplified in 'the Law') has long been a feature of Aboriginal societies (Glaskin 2005), and are not, in that sense, antithetical to each other, the question of how such dynamism might interact with the written legally enforceable rules of the constitution remains.

As these issues were debated among members of the claimant group, opinions emerged regarding the notion of 'traditional' and whether the use of such concepts by members of the claimant group actually represented a fidelity to tradition. A true understanding and application of 'tradition' was seen as an issue of considerable importance, for the rationale was that if traditional cultural principles ('rules') were sufficiently specified within the constitution, they would provide a base-line for determining process and authority through which internal conflicts over land could be resolved. In this sense, an expectation was placed on the constitution that it would act as an impersonal external authority on these matters (perhaps a bit like 'the Law'). The claimants maintained that the constitution of a $\mathrm{PBC}$ should reflect their culture, and therefore saw it as a matter of paramount importance to get the rules 'right'.

\section{'Tradition', property relations, and the constitution}

The talk concerning 'tradition' and the authority of the madjamadjin within a $\mathrm{PBC}$ constitution engendered diverse and shifting reactions among members and sectors of the claimant group. A consequence of this shifting political ground was that some members of the claimant group tended to view the recognition of 'traditional ownership' and systems of attachment to country by Australian law (within the native title context) as leverage through which they could protect their own interests in country. That is, prior to the determination of native title made in 2005, native title for them presented itself as a democratic outside enforcement of 'tradition', such that their rights and interests would be as recognised and protected as those of others in their own society. Throughout the native title process, a number of claimants maintained that they would not be involved in the claim unless they had secure undertakings that their specific rights in country would be recognised and respected by the rest of the claimant group, following a native title determination. Accordingly, they maintained a position that principles of land ownership (recognising specific interests in country, with reference to estates or bur(u) should be enunciated within the constitution for the PBC. Given that most Bardi and Jawi share this ideal, the principle became enshrined within clause 12.1 the draft constitution of the Bardi and Jawi PBC: 
In so far as it lies within the power of the Corporation to make a decision about a proposal affecting a particular Bur [estate], the Corporation shall, before carrying out or authorising or permitting the carrying out of any such proposal... have regard to the interests of, and consult with the common law holders of that Bur, or otherwise affected by a proposal, and take all reasonable steps to ensure that those Common Law Holders: (a) are informed; (b) understand the nature of the proposal; (c) have had the opportunity of expressing their views to the Corporation; and (d) consent to the proposal.

That is, the principle they frequently articulate, that the gamelid (often equated with patrifiliate or 'traditional owner') of the buru (estate) should have the 'top hand' or the 'final say' over what happens in their buru, was given an imprimatur of sorts within the draft constitution. The principle of who has 'final say' over country was stated; but the question of who specifically will have authority over particular buru will be contested in some cases. Some buru too will become deceased estates as their members die out; others are in the midst of processes of succession in the present (Bagshaw 2001: 41-2). There is plenty of scope then for contention over the elaboration of specifics within these principles. Clause 12.2. addresses this issue, again placing the madjamadjin in the role of arbitrating disputes and as the authorities on culture: 'Any disputes concerning a Bur, including a dispute as to the holder of an interest in that Bur, is to be resolved by the Governing Committee on advice from the Majamajin [sic], in accordance with Clause 13.'

The constitution thus not only prescribes general principles, but also processes (who is to be consulted; at what time, in what circumstances and contexts). The codification of principles and processes within portions of the draft constitution represents a transition from informal negotiations that may have occurred among the wider jural public over the same issues, and is an articulation elicited through engagement with native title. Such textual codification may transform 'social values and practices' by freezing these at a given point in time and thereby encouraging stasis in the system, and the system itself may dialectically evolve with reference to these representations (Mantziaris and Martin 2000: 43). Perhaps more consequentially, Mantziaris and Martin (ibid.) point to the possibility that such textualisation can 'result in the loss of control by the relevant indigenous people over the interpretation and content of their traditional laws and customs', which could fall to outside specialists such as lawyers and anthropologists. Contexts where this could occur is in 'litigation between indigenous people or between indigenous people and the native title corporation regarding the nature of their entitlements as against one another (their rights inter se)' (Mantziaris and Martin 2000: 66). 


\section{Conclusion}

In this chapter I have argued that the ways in which Bardi and Jawi have articulated and objectified aspects of their culture and identity through engagement with native title processes represents a different kind of objectification of their 'culture' than has previously arisen through colonial encounters. Further, I have suggested that codification arises in part through the native title process itself and in part through the claimants' dialectic engagement with native title, following such objectification. Weiner's description of the effects of codification amongst the Foi of Papua New Guinea is apposite to this discussion:

Although I have argued elsewhere that for the Foi, what we call law and the quality of being law- or rule-governed is not something that was consciously articulated, the coming of the government administration and Missionaries provided them with exposure to the idea that social law and customary action ... were something that could be objectified, codified and altered by human effort, rather than as phenomena that were only revealed in the course of humans reacting to otherwise situational and contingent social engagements and encounters (1998: 2).

Unlike other contexts in which the imposition of the colonial order, whether through the arrival of missionaries or otherwise, resulted in the codification of Indigenous customary law (Weiner and Glaskin 2006), my view is that this process has only begun to be realised among Bardi and Jawi as they engage communally with the processes of the Native Title Act. Through their engagement with the native title process, their principles of customary law are becoming explicit and formulated, and this reflects the formal elicitation of these (through various aspects of the native title process) and the informal elicitation of these that emerges dialectically among the group in response to the former.

While the state is able to circumscribe indigenous claims to country, and this may have an effect on the terms in which Aboriginal claims to country are articulated, this process should not be seen only in these terms. Elsewhere I have demonstrated something of the ways Bardi and Jawi have altered their own conditions of existence, using various strategies to negotiate their relationship with the state, its agents and its policies (Glaskin 2002: 80-105; 107-37). Like other historically constituted actions (such as their return from Derby to Sunday Island), their attempts to draft a constitution for their prescribed body corporate reflecting their 'culture' is an index of their agency, a strategy aimed at ensuring their survival and cultural reproduction.

The circumscription both explicit and immanent within native title (as legislation and as process) should not therefore be limited to being read as having the outcomes of objectification and incorporation of Indigenous groups, even though 
these are significant effects. Bardi and Jawi reactions to the native title process are manifold, and have resulted in much negotiation over aspects of 'tradition', 'culture', and 'authority' (to take a few examples) amongst them. These internal negotiations within the group were elicited through engagement with the native title process and are reflective of historical engagement with the state. They reveal an articulatory dialectic emerging within what Weiner, following Sahlins, calls 'the culture of the conjuncture, a relational moment that has particular historical and temporal as well as semiotic properties' (2000: 262). The boundaries between the 'internal' and the 'external' are constructed through this process, constituting the claimant group both to members of the group and to the state with which they are engaged.

But amongst Bardi and Jawi too, important 'dialectics of articulation' have been occurring, impacting social and political relations within the group. During the latter part of their Federal Court evidence in 2003, many of the claimants referred to themselves as 'Bardi-Jawi', a term which in 1994 had been primarily used self-referentially by those persons having one Bardi and one Jawi parent, not by Bardi and Jawi people per se. This was seemingly consequential for the judge's assessment of the nature of their contemporary society and how this related to Bardi and Jawi socio-linguistic identities in the pre-colonial context. While this is not the place for further discussion of this, it does demonstrate something of the effects of participating in native title processes on the ways that people articulate their identities in response to legal requirements, and signals something about how these articulations might transform over a short period of time. In litigation, much is read into these kinds of objectifications of identity, which might otherwise appear as the kind of shifting ground of articulation occurring commonly in societies in relation to various social processes, and which may indeed reflect temporary responses rather than real ontological or societal transformations.

Quite apart from the form of legal recognition finally made in native title determinations, one of the consequences of engaging in the native title process is the effect this may have on a group's own property relations, on how these relations are articulated and objectified, and perhaps, subsequently codified (and see Glaskin 2007). Amongst Bardi and Jawi, during the PBC discussions preceding their determination, significant questions were raised; not just about their relationship with the state (historically and contemporarily), but also with respect to how they conceptualised and constituted themselves. These questions alone are significant, but they also have important consequences for the descendants of the current generations and for the ongoing reproduction of their culture and property relations over time. 


\section{Acknowledgements}

This paper is substantially drawn from my $\mathrm{PhD}$ research (Glaskin 2002), which would not have been possible without the assistance of the Kimberley Land Council and The Australian National University. I particularly wish to thank my supervisors, Francesca Merlan, Ian Keen and Tim Rowse, for their comments and advice along the long thesis road. I wish also to thank the Berndt Foundation at the University of Western Australia for the postdoctoral fellowship that allowed me to continue writing and thinking about these things. James Weiner and David Trigger provided comments on an earlier draft of the paper on which this chapter is based, and I am grateful to them. I am especially grateful to Geoffrey Bagshaw (my long-term anthropological colleague in this case), and to the many Bardi and Jawi people (including those now deceased) who have generously shared their lives and struggles with me over many years.

\section{References}

Bagshaw, G. C. 1999. Native Title Claim WAG 49/98 (Bardi and Jawi) Anthropologist's Report, a report prepared for the Kimberley Land Council on behalf of the native title claimants, February, 1999, Kimberley Land Council, Derby.

Bagshaw, G. C. 2001. 'Applicants' additional anthropological report concerning distribution and spatial extent of local estates (bur[u]) within the Bardi and Jawi native title claim area', filed in the Federal Court of Australia, Western Australia District Registry, General Division, in Paul Sampi \& Ors vs The Premier and State of Western Australia \& The Commonwealth of Australia, WAG 49/1998, 8 February 2001.

Barth, F. 1970. 'Introduction', in F. Barth (ed.), Ethnic Groups and Boundaries: the Social Organization of Culture Difference, George Allen \& Unwin, London.

Bates, D. M. 1966 [1938]. The Passing of the Aborigines. William Heinemann, Melbourne.

Bates, D. M. 1985. The Native Tribes of Western Australia (I. White ed.), National Library of Australia, Canberra.

Bates, D. M. n.d. Box 27, Items 53/110, 53/111,53/116, Records of Daisy M. Bates, MS 365, Manuscript Section, National Library of Australia, Canberra.

Bates, D. M. n.d. Box 50, Items 97/439-458, Records of Daisy M. Bates, MS 365, Manuscript Section, National Library of Australia, Canberra.

Bird, W. H. 1910. 'Some remarks on the grammatical construction of the Chowielanguage, as spoken by the Buccaneer Islanders, North-Western Australia', Anthropos, 5: 454-6. 
Bird, W. H. 1911. 'Ethnographical notes about the Buccaneer Islanders, North Western Australia', Anthropos, 6: 174-8.

Bird, W. H. 1915. 'A short vocabulary of the Chowie-language of the Buccaneer Islanders (Sunday Islanders), North Western Australia', Anthropos, 10: 180-6.

Bourdieu, P. 1977. Outline of a Theory of Practice, Cambridge University Press, Cambridge.

Culhane, D. 1998. The Pleasure of the Crown: Anthropology, Law and First Nations, Talon Books, Burnaby, Vancouver.

Durack, M. 1997 [1969]. The Rock and the Sand, Corgi, London.

Federal Court Transcript WAG 49/98, Paul Sampi \& Ors v State of Western Australia \& Ors [2001], prepared by Transcript Australia.

Glaskin, K. 2002. Claiming Country: a Case Study of Historical Legacy and Transition in the Native Title Context, PhD Thesis, The Australian National University, Canberra.

Glaskin, K. 2003. 'Native title and the "bundle of rights" model: implications for the recognition of Aboriginal relations to country', Anthropological Forum, 13 (1): 67-88.

Glaskin, K. 2005. 'Innovation and ancestral revelation: the case of dreams', Journal of the Royal Anthropological Institute, 11 (2): 297-314.

Glaskin, K. (2007). 'Outstation incorporation as precursor to a prescribed body corporate', in J. F. Weiner and K. Glaskin (eds), Customary Land Tenure and Registration in Indigenous Australia and Papua New Guinea: Anthropological Perspectives, Asia-Pacific Environment Monograph 3, ANU E Press, Canberra.

Hallowell, A. I. 1955. Culture and Experience, University of Pennsylvania Press, Philadelphia.

Keen, I. 1997 [1994]. Knowledge and Secrecy in an Aboriginal Religion, Oxford University Press, Melbourne.

Kimberley Land Council 1998. Draft Constitution for the Bardi and Jawi Prescribed Body Corporate 1998, unpublished typescript, Kimberley Land Council, Derby.

Kolig, E. 1981. The Silent Revolution: the Effects of Modernization on Australian Aboriginal Religion, Institute for the Study of Human Issues, Philadelphia.

Mantziaris, C. and Martin, D. 2000. Native Title Corporations: a Legal and Anthropological Analysis, The Federation Press, Sydney. 
Merlan, F. 1998. Caging the Rainbow: Places, Politics and Aborigines in a North Australian Town, University of Hawai'i Press, Honolulu.

Myers, F. 1986. Pintupi Country, Pintupi Self: Sentiment, Place, and Politics among Western Desert Aborigines, Smithsonian Institute, Washington.

Munn, N. 1970. 'The transformation of subjects into objects in Walbiri and Pitjantjatjara myth', in R. M. Berndt (ed.), Australian Aboriginal Anthropology, University of Western Australia Press, Perth.

Patton, P. 2000. 'The translation of indigenous land into property: the mere analogy of English jurisprudence', Parallex, 6 (1): 25-38.

Robinson, M. V. 1973. Change and Adjustment among the Bardi of Sunday Island, North-Western Australia, MA Thesis, University of Western Australia, Perth.

Roosens, E. 1989. Creating Ethnicity: the Process of Ethnogenesis, Frontiers of Anthropology, Vol. 5, Sage Publications, Newbury Park.

Rouja, P. M. 1998. Fishing for Culture: Toward an Aboriginal Theory of Marine Resource Use among the Bardi Aborigines of One Arm Point, Western Australia, PhD Thesis, University of Durham, Durham.

Rumsey, A. 1994. 'The Dreaming, human agency and inscriptive practice', Oceania, 65 (2): 116-30.

Scott, C. H. 1993. 'Custom, tradition, and the politics of culture: Aboriginal selfgovernment in Canada', in N. Dyck and J. B. Waldram (eds), Anthropology, Public Policy, and Native Peoples in Canada, McGill-Queen's University Press, Montreal and Kingston.

Strathern, M. 1999. Property Substance and Effect: Anthropological Essays on Persons and Things, The Athlone Press, London.

Sullivan, P. 1997. 'Dealing with native title conflicts by recognising Aboriginal political authority', in D. E. Smith and J. Finlayson (eds), Fighting over Country: Anthropological Perspectives, CAEPR Research Monograph No. 12, Centre for Aboriginal and Economic Policy Research, The Australian National University, Canberra.

Thomason, B. C. 1982. Making Sense of Reification: Alfred Schutz and Constructionist Theory, Humanities Press, Atlantic Highlands, New Jersey.

Wagner, R. 1981 [1975]. The Invention of Culture, University of Chicago Press, Chicago.

Weiner, J. F. 1998. 'The incorporated ground: the contemporary work of distribution in the Kutubu oil project area, Papua New Guinea', Resource Management in Asia-Pacific Working Paper No. 17, Division of Pacific 
and Asian History, Research School for Pacific and Asian Studies, The Australian National University, Canberra. Available from:

http://coombs.anu.edu.au/Depts/RSPAS/RMAP/weiner.htm, accessed 9 July 2007.

Weiner, J. F. 2000. 'The epistemological foundations of contemporary Aboriginal religion: some remarks on the Ngarrindjeri', Aboriginal History, 24:

260-3.

Weiner, J. F. and Glaskin, K. 2006. 'Introduction: the (re-) invention of Indigenous laws and customs', The Asia Pacific Journal of Anthropology, 7 (1): $1-13$.

Worms, E. A. 1940. 'Religiöse Vorstellungen und Kultur einiger Nord-Westaustralischer Stämme in fünfzig Legenden', Annali Lateranensi, 4: 230-82.

Worms, E. A. 1942. 'Die Gonara-Feier im Australischen Kimberley', Annali Lateranensi, 6: 207-35.

Worms, E. A. 1944. 'Aboriginal place names in the Kimberley, Western Australia: an etymological and mythological study', Oceania, 14 (4): 284-310.

Worms, E. A. 1949. 'An Australian migratory myth', Primitive Man, 22 (1-2): $33-8$.

Worms, E. A. 1950. 'Feuer und Feuerzeuge in Sage und Brach der NordwestAustralier', Anthropos, 45: 145-64.

Worms, E. A. 1957. 'Australian mythological terms, their etymology and dispersion', Anthropos, 52: 732-68.

Worms, E. A. 1959. 'Verbannungslied eines Australischen Wildbeuters: ein Beitrag zur Lyrik der Bad', Anthropos, 54: 154-68. 